\title{
Security Measures and Liability Measures in Loan Agreements
}

\author{
Artur Ilfarovich Khabirov ${ }^{1} \&$ Gulnara Mullanurovna Khamitova ${ }^{2}$ \\ ${ }^{1}$ Kazan Federal University, Russia \\ ${ }^{2}$ Kazan State Medical University, Russia \\ Correspondence: Artur Ilfarovich Khabirov, Kazan Federal University, Russia. E-mail: art.khabir@gmail.com
}

Received: June 9, 2019

Accepted: August 25, 2019

Online Published: August 31, 2019

doi:10.5539/jpl.v12n5p1

URL: https://doi.org/10.5539/jpl.v12n5p1

\begin{abstract}
The Civil Code of the Russian Federation regulates the use of various measures to protect violated rights and interests: first, these include universal methods for protecting civil rights (article 12 of the Civil Code); second, these include provisions of Chapter 25 of the Civil Code regarding the liability for violating one's obligations; both of them jointly comprising the institution of protection of civil rights. This article studies the issue of consequences for violating a party's duties under a loan agreement. The article differentiates safeguarding measures and liability measures to be used in case of an offense. The article also makes a conclusion regarding whether such differentiation is appropriate. Based on such differentiation, we analyze Paragraph 1 of Chapter 42 of the Civil Code of the Russian Federation.
\end{abstract}

Keywords: loan agreement, civil legal protection, relief, retaliatory measures, public coercive measures, abuse of rights, liabilities, losses

\section{Introduction}

The universal protections of civil rights listed in Article 12 of the Civil Code of the Russian Federation can be divided into two main groups: protective measures and liability measures, which depend on the legal nature of the specific measure, its functions and consequences. However, such dichotomy is not always observed. Thus, Article 12 of the Civil Code of the Russian Federation lists compensation of losses as a method of protecting civil rights, although by claiming losses, the creditor does not insist on performing the obligation, but wants to compensate their incurred and future expenses to recover their funds.

\section{Methods}

This study is based on the method of analyzing effective Russian legislation and case law, as well as effective European / global standards for the purpose of legal unification. The legal modeling method and the legal forecasting method allow us to determine the need for amending the effective Russian law, as well as correcting the litigation practices. By using the modeling and forecasting methods, we are able to determine the consequences of such changes and corrections with a sufficient degree of certainty, and to identify how closely Russian case law will approach existing European / global standards. The legal sociological method allows us to evaluate social problems from the legal perspective, from the perspective of legislation and enforcement. The interpretation method supplements the comparative law analysis in this research, enabling us to understand and compare Russian and European / global legal standards. The use of various methods helped formulate the key theoretical conclusions and provide original suggestions in the subject area.

\section{Results and Discussion}

Meanwhile, protective measures and liability measures should be strictly differentiated using several criteria. The first criterion is the functional one. Civil and legal liability measures have a compensatory function and a recovering function, while protective measures also implement preventive and retaliatory functions. Available literature correctly notes that liability has such features as "prevention, coercion and punishment". However, for the purposes of differentiating between the public and private regulation, and between criminal and civil law, civil law is "based on the goal of recovering the initial status".

The second criterion is the consequences of implementation. In case of applying civil law liability, the offender suffers the burden of liabilities, i.e. civil law sanctions. Meanwhile, the use of protective measures typically does not cause the subject of such measure to acquire new liabilities. The third criterion is the conditions of use. To use 
liability measures against an offender, their behavior must be subjectively characterized by guilt, which does not require protective measures. Thus, one of the main positions in defining the notion of civil law liability is the theory of influence based on the concept of guilt.

The need for differentiating civil law liability measures from protective measures is determined not only by scientific importance (clarifying the categories), but also has practical use. Thus, in the event of a non-performance or improper performance of the debtor's financial duties, both the demand to compensate losses and the demand to force the debtor to perform their duties will ultimately manifest in a monetary amount, the value of the lawsuit. The value of the lawsuit often includes the principal, penalties and interest for unlawful use of funds; however, plaintiffs should take into account that the demand for collecting the principal under a monetary obligation is a demand to force to perform a duty (a civil law protective measure), while other demands above request for the debtor to be held liable. Accordingly, if the debtor is held liable, their guilt should be established and other factors should be taken into account, such as: reduced liability in case of combined guilt of the debtor and the lender (Article 404 of the Civil Code of the Russian Federation); cases of limited liability (Article 400 of the Civil Code of the Russian Federation), and taking into the account the financial situation of the individual who causes losses.

Interestingly, German law, which is the most progressive in terms of determining the liability, and with which Russian law is strongly connected due to the common Roman legal traditions, "guilt-based liability has a prerequisite of harm (Schaden), cause-and-effect link (Verursachung, condition sine qua non, supplemented with the theory of adequacy), unlawfulness (Rechtswidrigkeit) and guilt (Verschulden - subjective reprehensibility of the unlawful behavior)". The same prerequisites were developed in the Russian theory of civil law liability.

Civil law provides several classifications for measures of protecting civil rights. According to one such classification developed by V. P. Gribanov, which is also cited in contemporary studies of civil law, civil law protection measures can be divided into three types. First, this is the right of self-protection of civil rights; second, the right to use retaliatory measures permitted by law against the offender; and third, the right to petition competent public bodies or institutions and demand public coercive measures to be applied against the offender.

In loan agreements, a measure that protects the rights of both parties and is neither a protective measure nor a liability measure is the fact that the loan agreement is to be executed in writing regardless of the amount, despite Paragraph 1, Article 808 of the Civil Code of the Russian Federation that permits verbal loan agreements if the amount does not exceed one thousand rubles. Executing the loan agreement in writing has the effect of creating discipline among the parties, contributing to the proper performance of the borrower's obligations, and creating a barrier for disputing the agreement due to the lack of funds.

Lender's retaliatory measures against the borrower include: 1) demanding early repayment if the loan was granted for a particular purpose and it is found that the loaned amount is being spent for other purposes, or if the borrower does not permit assessing that the funds are being used for the stated purpose (Paragraph 2, Article 814 of the Civil Code of the Russian Federation); 2) demanding early repayment of the entire principal that was originally due to be repaid in instalments if the borrower fails to repay an instalment on time (Paragraph 2, Article 811 of the Civil Code of the Russian Federation); 3) demanding early repayment of the principal if the borrower fails to provide a collateral specified in the loan agreement, or if the collateral is lost or deteriorates (Article 813 of the Civil Code of the Russian Federation).

Protective measures exercised by the lender solely through competent authorities include the demand to hold a defaulting borrower criminally liable for wilful evasion of repayment of debt (Article 177 of the Criminal Code of the Russian Federation), or for borrowing fraud, i.e. theft of funds by borrower by providing the bank or another lender with information that is known to be false or untrue (Article 159.1 of the Criminal Code of the Russian Federation), or holding them administratively liable in case they obtain a loan or favorable terms of a loan by providing information about its business or finance that is known to be false (Article 14.11 of the Administrative Code of the Russian Federation).

Despite the unilaterally binding nature of the loan agreement, the lender can also be held liable for violating the borrower's rights. We note a specific case of violations by the lender / creditor. A lender may violate the agreement by abusing their rights. Actions that are considered an abuse of their right (Article 10 of the Civil Code) include the lender's failure to accept the repaid amount after the specified time or if the borrower is entitled to early repayment, which is generally considered permissible in relations between individuals (Article 315 of the Civil Code), and is also permissible in loan agreements that are free of charge or when the borrowing individual was granted the loan for personal, domestic, or household use, or for other purposes unrelated to a business (Paragraph 2, Part 2, Article 810 of the Civil Code). 
A lender is considered to be in default if they 1) fail to provide details of the account where the repayment should be made to, 2) fail to meet the borrower, 3) fail to return the evidence of debt to the borrower. In that case, a borrower can protect their rights by using a retaliatory measure of depositing the principal and interest at a notary. From that moment, the borrower's obligation shall be considered fulfilled, and no late interest would accrue (Paragraph 3, Article 406 of the Civil Code). As a general rule, if the lender defaults, the borrower may claim losses caused by such default. Nevertheless, as N. V. Karpova correctly states, this rule is not applicable to the relationships under a loan agreement, since a lender that defaults is in fact continuing to lend money to the borrower free of charge, and therefore the losses are incurred by the lender. The borrower in that case does not suffer losses except when the borrower needs to incur an additional expense to preserve any property.

Finally, a borrower may file a lawsuit to dispute a loan agreement due to the lack of funds (Article 812 of the Civil Code). In that case, the borrower's rights are protected through the litigation procedure, because the dispute concerns civil law. Therefore, the burden of proof lies on the borrower, since referring to such fact (failure to receive or failure to completely receive the subject of the loan) is the basis of the lawsuit. In accordance with Paragraph 1, Article 56 of the Civil Procedure Code, each party shall prove the circumstances they are referring to as the basis of their claims and objections. The subject of the lawsuit under Article 812 of the Civil Code will not be to recognize the transaction as void, but to recognize the loan agreement as unexecuted or executed for a smaller amount of funds or property. The legislators' use of the term "dispute" in Article 812 of the Civil Code should not mislead us to conclude that it deals with rendering the disputed deal void, because to do so, the deal must be executed and the agreement must be signed. For that reason, in this case the agreement is recognized as unexecuted, rather than the deal is recognized as having deficiencies that render it void. Thus, disputing a loan agreement under Article 812 of the Civil Code shall be understood as the borrower's claim in court to recognize the agreement as unexecuted. If one of the parties to the loan agreement is a legal entity, it will be easier to establish truth in the case, because according to the Federal Law "On Accounting", all liabilities of an organization are subject to accounting and shall be recorded in the accounts without any omissions. Furthermore, in accordance with Paragraph 1, Article 9 of that law, all business transactions of an organization shall be evidenced by documents. If a loan agreement is deemed to be unexecuted, the parties should be restored to their initial state.

\section{Summary}

To sum up the above, Russian law permits parties of a loan to use preventive measures (executing the loan between individuals in writing regardless of the amount), protective measures and liability measures against a defaulting party. Protective measures can be classified into retaliatory measures against the defaulting party, and measures used solely by competent state authorities. Retaliatory measures by the lender include the right to demand early repayment of the entire principal when 1) the loaned amount is being spent for an inappropriate purpose, or the lender is unable to control the spending (Paragraph 2, Article 814 of the Civil Code of the Russian Federation); 2) the borrower fails to pay an instalment (Paragraph 2, Article 811 of the Civil Code); the borrower fails to provide proper collateral for the loan (Article 813 of the Civil Code). When the lender abuses their general lender's duty to accept a proper repayment of the loan, the borrower may protect their rights by depositing the principal and interest at a notary. Public coercive measures include: a) the borrower disputing the loan agreement in court on the basis of the lack of funds, and b) demanding a court order to force a party to perform a duty. Using protective measures does not require a proof of guilt of the defaulting party.

Liability measures include compensation of losses and recovery of damages. Despite the apparent similarity of the lender's methods to protect their rights under a loan agreement - requiring a forced performance of a duty and compensation of losses / recovery of damages - their legal nature is different: compensation of losses and and recovery of agreed damages or damages permitted by law are civil law measures. Therefore, when an additional burden of liability is imposed on the defaulting party by a court, the court should take into account the provisions of the Civil Code of the Russian Federation about reducing the damages (Article 333 of the Civil Code), taking into account the financial situation of the individual that causes damages (Article 1074 of the Civil Code); the offender's guilt, causal effect, fact of damages and unlawfulness must be established (Article 401 of the Civil Code). Liability measures against the borrower also include criminal liability (Article 159.1, 177 of the Criminal Code of the Russian Federation) or administrative liability (Article 14.11 of the Administrative Code of the Russian Federation).

\section{Conclusions}

However, despite the legal protective powers granted to the parties, the number of loan agreement related offences continues growing, as evidenced by the statistics. This means that current law requires further adjustment. 


\section{Acknowledgements}

The work is performed according to the Russian Government Program of Competitive Growth of Kazan Federal University.

\section{References}

Arslanov, K. M. (1999). Functions of the legal institution of compensation of moral harm in offenses against the honor, dignity, business reputation and private life of citizens in Russian and German law: thesis for the Candidate of Legal Sciences. Kazan.

Arslanov, K. M. (2012). On the mutual connection between Russian civil law and German legal system. Proceedings of Kazan University Series: Humanitarian Sciences. Volume 154, book 4. P. 67-73.

Arslanov, K. M. (2013). The notion of civil law liability in German law. Proceedings of Kazan University Series: Humanitarian Sciences. Vol. 155, Book 4. P. 101.

Artur, K. (2018). On the issue of the consensual construction of a loan agreement. National Academy of Managerial Staff of Culture and Arts Herald, (3), 70-73.

Blinnikov, L. A. (2005). Lending relations with individuals: thesis for the Candidate of Legal Sciences. Krasnodar.

Braginsky, M. I., \& Vitryansky, V. V. (2006). Lending law, Book 5, volume 1: Loan, bank credit and factoring agreements. Agreements for creating collective entities. Moscow: Statut.

Bush, I. A. (2011). Protecting the rights of parties to rental relationships under Russian law: Thesis for a Candidate of Legal Sciences. Saratov.

Chegovadze, L. A. (2013). On protecting civil rights and liability for violation thereof. Lawyer, (12), 8.

Civil law: textbook: in 3 volumes. Volume 1 / Abramova, E.N., Averchenko, N. N., Baigusheva, Yu. V. [and others]; edited by Sergeyev, A. P. - Moscow: TK Velbi, 2009. - P. 546 (The author of Chapter 17 "Protection of civil rights" is Sergeyev, A. P.).

Dale, W. (1977). Legislative Drafting: A New Approach: a Comparative Study of Methods in France, Germany, Sweden and the United Kingdom. London: Butterworths.

Davies, P. (2016). Rectification versus interpretation: the nature and scope of the equitable jurisdiction. The Cambridge Law Journal, 75(1), 62-85. https://doi.org/10.1017/S0008197315000975

Gribanov, V. P. (1973). Liability for violating civil rights and duties. Moscow, "Znanie".

Karpova, N. V. (2007). Loan liabilities in civil law of the Russian Federation: thesis for the Candidate of Legal Sciences. Moscow.

Khabirov, A. I. (2014). On the abuse of the lender's rights under loan agreements. In Z. F. Khusainova (Ed.), Digest of postgraduate research of the Law Department of the Kazan Federal University (Issue 15, pp. 127-132). Kazan: Kazan University Publishing House.

Khabirov, A. I., \& Khamitova, G. M. (2018). Legal problems of vaccinal prevention. Dilemas Contemporaneos-Educacion Polit-Ica Y Valores, 6(39).

Khabirov, A. I., \& Khamitova, G. M. (2018). On The Issue of the Place of a Loan Commitment in the System of the Russian Law of Obligations. The Journal of Social Sciences Research, 5, 421-424. https://doi.org/10.32861/jssr.spi5.421.424

Kozyr, O. M., Makovsky, A. L., \& Khokhlov, S. A. (Eds.). (1996). On the unilateral nature of a loan agreement see e.g.: Civil Code of the Russian Federation P. 2: Text, commentary, index. Moscow.

Krasavchikov, O. A. (2005). Liability, protective measures and sanctions in Soviet civil law. O. A. Krasavchikov Categories of science of civil law: selected works: in 2 volumes. Moscow: Statut.

Paragraph 10 of the Decree No. 13 of the Plenum of the Supreme Court of the Russian Federation, Decree No. 14 of the Plenum of the Supreme Arbitration Court of the Russian Federation dated 8 October 1998 (as amended on 4 December 2000) "On the practice of applying provisions of the Civil Code of the Russian Federation regarding interest". Retrieved from http://www.consultant.ru/document/cons_doc_LAW_29811

Siems, M., \& Mac Síthigh, D. (2012). Mapping legal research. The Cambridge Law Journal, 71(3), $651-676$. https://doi.org/10.1017/S0008197312000852

Sukhanov, E. A. (Ed.). (2010). Russian civil law: Textbook: 2 volumes. Moscow: Statut. P. 420-422. 
The number of cases of non-performance or improper performance of duties under loan and credit agreements in 2013 has increased by $2.5 \%$ compared to 2012 . Retrieved from http://www.arbitr.ru/_upimg/6A5186F13476D4165EB471E30FE28547_3.pdf

\section{Copyrights}

Copyright for this article is retained by the author(s), with first publication rights granted to the journal.

This is an open-access article distributed under the terms and conditions of the Creative Commons Attribution license (http://creativecommons.org/licenses/by/4.0/). 